\title{
GERACÕES DA INDEPENDÊNCIA: DIVERSIDADES GERACIONAIS NA IMPRENSA DO BRASIL ENTRE 1808 E 1831
}

LUÍS OTÁVIO VIEIRA* UNIVERSIDADE DE SÃO PAULO SÃO PAULO - SÃO PAULO - BRASIL

O presente artigo busca explorar algumas possibilidades de investigação da Independência como um nexo de ações de diferentes gerações, e como essa distinção geracional pode ser percebida na ação e discursos políticos de diferentes agentes da imprensa da época. Pretendemos apontar as diferenças etárias como elementos constituintes das trajetórias, das ações individuais e, também, como limites fronteiriços entre elas. Buscaremos demonstrar a efetividade da História dos

\section{RESUMO} Conceitos e a forma como ela lida com as experiências históricas como meio de identificar as quebras geracionais dentro do conjunto de nossos personagens. E com o auxílio das ferramentas conceituais desenvolvidas por Karl Mannheim, ao lidar com o tema das gerações, daremos contornos mais nítidos ao quadro multigeracional da Independência.

Palavras-chave: Independência; Imprensa; Geração.

This article seeks to explore some possibilities for investigating Independence as a nexus of actions of different generations, and how this generational distinction can be perceived in the action and political discourses of different press agents of the time. We intend to point out age differences as constituent elements of individual trajectories and actions and also as boundary boundaries between them. We will seek to demonstrate the effectiveness of the History of Concepts and the way it deals with historical experiences as a means of identifying generational breaks within the set of our characters. And with the help of the conceptual tools developed by Karl Mannheim, when dealing with the theme of generations, we will give clearer contours to the multigenerational framework of Independence.

Keywords: Independency; Press; Generation.

* Mestre em História Social pela Universidade de São Paulo e membro do Laboratório de Estudos sobre o Brasil e o Sistema Mundial (LabMundi/ USP). E-mail: luis_vieira_mail@yahoo.com.br. 


\section{INTRODUCÃO}

O período entre 1808 e 1831, em que se desenrolou o processo de Independência do Brasil $^{1}$, corresponde, em intersecção com as demais independências hispanoamericanas e o mundo ibero-americano como um todo, ao momento chave do conjunto de transformações ocorridas entre o final do século XVIII e a primeira metade do século XIX que se convencionou chamar de Era das Revoluções ${ }^{2}$. De acordo com Javier Fernández Sebastián, esse mesmo intervalo temporal caracterizou-se por um desenrolar de eventos dotados de "intensidade insólita, que a partir de 1808 y en apenas dos o tres décadas, cambiaron profundamente la faz de nuestros países y supusieron para sus habitantes la entrada en ese nuevo marco histórico y político al que solemos aludir abreviadamente con la palabra modernidad" ". Nessas transições do Antigo Regime para realidades modernas ${ }^{4}$, onde valores e instituições sofriam transformações políticas e sociais, entre rupturas e continuidades, a denominação de diversas ou de uma grande crise parece fazer justiça a esse amplo cenário.

Fenômeno contemporâneo e indissociável à Independência, o desenvolvimento da opinião pública na América portuguesa, instituição típica da modernidade, igualmente sinaliza nessa crise a transição entre o Antigo Regime e a modernidade ${ }^{5}$. Materializada, sobretudo, na imprensa, suporte fundamental do debate público, Marco Morel baliza o surgimento da opinião pública nos territórios portugueses na América a partir de 1820, quando entram em vigor os decretos sobre liberdade de imprensa expedidos pelas Cortes

\footnotetext{
${ }^{1}$ Utilizamos aqui a mesma periodização proposta por Caio Prado Junior para cobrir o processo de Independência, aceita por significativa parte da historiografia até hoje. PRADO JUNIOR, Caio. Evolução Política do Brasil. São Paulo: Brasiliense, 1971. De acordo com Pimenta: "creio poder afirmar que, atualmente, nenhum estudioso da Independência seria capaz de ignorar a necessidade de inserir seu objeto de estudo em uma temporalidade que confira centralidade, pelo menos, aos acontecimentos de 1808; já a possibilidade de se ir além, para trás ou para frente, é uma questão em aberto. A outorga da Carta constitucional de 1824 , o reconhecimento luso britânico da Independência (1825), a crise e o fim do Primeiro Reinado (1831) com a "nacionalização" da monarquia, o período das Regências (1831-1840), todos oferecem marcos temporais pertinentes, não-excludentes, e que apontam, inclusive, para a complexidade e dinâmica da Independência como um processo". Ver PIMENTA, João Paulo. A independência do Brasil como uma revolução: história e atualidade de um tema clássico. História da Historiografia, v. 3, 2009 , p.69.

${ }^{2}$ HOBSBAWM, Eric J. A Era das Revoluções, Europa 1789-1848. Rio de Janeiro: Paz e Terra, 1977.

${ }^{3}$ FERNÁNDEZ SEBASTIÁN, Javier (dir.), Diccionario político y social del mundo ibero-americano: La era de las revoluciones, 1750-1850. [Iberconceptos I], Madrid, Fundación Carolina / CEPC, 2009, p. 35.

${ }^{4}$ Modernidade pode ser entendida como um tipo ideal ou um conceito simétrico a Antigo Regime, termos que dividem duas realidades separadas pelas revoluções entre 1750 e 1850 . Para o caso brasileiro explorado nesse artigo, a modernidade se caracteriza por novas formas de organização social, novas instituições e princípios políticos que passam a reger o nascente Estado nacional surgido após a revolução de Independência. Esses elementos tomam seus contornos em contrapartida com as formas de organização social, instituições e princípios políticos do Antigo Regime, ou seja, da realidade anterior à revolução de Independência. A própria experiência em relação ao tempo e à história se altera, implicando nessa periodização. Todavia, não obstante essas rupturas, tão importan tes quanto elas são as inevitáveis continuidades entre os dois períodos. FERNÁNDEZ SEBASTIÁN, Javier (dir.), Diccionario político y social del mundo... op., cit., p. 36-37. ARAUJO, Valdei Lopes. A experiência do tempo: conceitos e narrativas na formação nacional brasileira (1813-1845). São Paulo: Hucitec, 2008. MACHADO, André Roberto de A. A quebra da mola real das sociedades: a crise política do antigo regime português na província do Grão-Pará(1821-1825). São Paulo: Hucitec / FAPESP, 2010.

${ }^{5}$ MOREL, Marco; BARROS, Mariana Gonçalves Monteiro de. Palavra, imagem e poder: o surgimento da imprensa no Brasil do século XIX. Rio de Janeiro: DP\&A, 2003, p.7.
} 
de Lisboa, desdobramentos da Revolução do Porto ${ }^{6}$. A partir daí, Independência, imprensa e opinião pública passam a se conformar mutuamente, sendo plausível classificar os redatores e editores de periódicos da época como atores de destaque na ruptura política entre Brasil e Portugal e na subsequente formação do Estado brasileiro? .

Considerando a relação de mutualidade e simbiose entre desenvolvimento da trajetória do indivíduo e da sociedade na qual ele está inserido, atentamos que a observação de características e cursos de vida individuais significa necessariamente a observação da dinâmica social. Pois, "tudo aquilo que chamamos estruturas e leis sociais não são nada além de estruturas e leis das relações entre as pessoas"8. Portanto, contemplar trajetórias dos produtores de periódicos ${ }^{9}$ em atividade no Brasil entre 1808 e 1831 incorre, em uma dimensão importante, em levantar elementos da própria Independência.

Entre 1808 e 1831 decorreram pouco mais de duas décadas, tempo considerável para uma trajetória política individual. Tempo suficiente de maturação, por exemplo, de indivíduos ainda na infância, na primeira ponta do intervalo, em personagens aptos a desempenhar papéis importantes em conjunturas mais próximas da ponta final. Utilizando um exemplo concreto: Antônio Borges da Fonseca, célebre redator e editor de $O$ Repúblico (10/1830 a 7/1831; 1832 a 1855), periódico de destaque nos anos finais do primeiro Reinado, nasceu justamente em 1808 e possuía apenas catorze anos de idade em 1822. Dessa forma, pouco participou dos acontecimentos compreendidos entre a chegada da família real e a formalização da ruptura entre Brasil e Portugal, atuando como produtor de periódico a partir de 1828, no fim do Primeiro Reinado.

Já José da Silva Lisboa, magistrado, produtor de periódicos, deputado e senador, nascido em 1756, participava de decisões políticas estatais da mais alta importância desde 1808, quando tomou parte na abertura dos portos, e assim permaneceu até 1831, quando

\footnotetext{
${ }^{6}$ MOREL, Marco. As transformações dos espaços públicos: imprensa, atores políticos e sociabilidades na cidade imperial (1820 1840). São Paulo: Hucitec, 2005. MOREL, Marco. La génesis de la opinión pública moderna y el proceso de independencia (Río de Janeiro, 1820-1840). In: GUERRA, François-Xavier; LEMPÉRIÈRE, Annick.(Org.). Los espacios públicos en Iberoamérica. Ambigüedades y problemas. Siglos XVIII y XIX. México, Centro Francés de Estudios Mexicanos y Centroamericanos - FCE, 1998.

${ }^{7}$ Antes de 1820, porém, a imprensa se fazia presente na América portuguesa desde 1808, quando a Corte em fuga trouxe consigo o equipamento que deu origem à Impressão Régia. Essa e outras poucas oficinas tipográficas surgidas até 1820, assim como os impressos que produziram, conformaram uma imprensa típica do Antigo Regime, sob a rígida tutela da monarquia absolutista e sua censura. Dessa maneira, os impressos não eram ferramentas e veículos de opinião e participação no debate público a disposição dos indivíduos, ou grupos de indivíduos, para além dos desígnios do Estado. Portanto, uma imprensa apartada do desenvolvimento da opinião púb lica. ${ }^{8}$ ELIAS, Norbert. A sociedade dos indivíduos. Rio de Janeiro Jorge Zahar Editor, 1994.

${ }^{9}$ Adotamos o termo produtores de periódicos por localizar na fase de produção de impressos a etapa comum de atividade de redato res e editores dentro de um circuito de comunicação mais amplo. Esse circuito continha outras fases que sucediam à de produção, como a de circulação e comercialização dos periódicos e sua posterior leitura e recepção já nas mãos do leitor. Sobre circuito de comunicação, ver DARNTON, Robert. A questão dos livros: presente, passado e futuro. São Paulo: Companhia das Letras, 2010, p. 144.
} 
ocupava uma cadeira no Senado ${ }^{10}$. Silva Lisboa também integrava o que parte da historiografia acerca dos séculos XVIII e XIX do Brasil denominou de geração de 1790: um grupo de ilustrados portugueses, formados principalmente pela reformada Universidade de Coimbra, planejadores e executores das principais reformas ilustradas portuguesas em fins do século XVIII e pensadas para o início do século XIX. O grupo tinha como grande referencial e centro convergente o ministro D. Rodrigo de Sousa Coutinho, o Conde de Linhares, e, entre eles, havia a presença de muitos portugueses de origem americana ${ }^{11}$.

Nomes dessa chamada geração de 1790 tornaram-se personagens de imensa relevância para a independência, uma vez que para parte desses indivíduos os próprios projetos reformistas portugueses converteram-se, sob a força das circunstâncias, em projetos independentistas e de criação de um Estado Nacional brasileiro. Isso é constatável nas trajetórias de indivíduos como o próprio Silva Lisboa e ainda José Bonifácio (nascido em 1763), ambos atuantes tanto na Corte do Rio de Janeiro quanto na imprensa periódica ${ }^{12}$. Evidente que Borges da Fonseca, nascido já no século XIX, não poderia figurar nesse grupo; todavia, isso não diminui seu papel nos desdobramentos finais do processo de Independência, mesmo estando fora dos limites desse grupo cujo nome traz o termo geração, usualmente utilizado para delimitar fronteiras temporais com base em faixa-etárias. Nesse caso, seria verossímil entender a Independência também como um palco de ação multigeracional, onde grupos distintos entre si, por características atreladas à faixa-etária e datas de nascimento de seus componentes, encontram-se e atuam em conjunturas comuns.

O presente artigo toma parte dos resultados alcançados em trabalho anterior ainda inédito $^{13}$, com o acréscimo de novas reflexões, no intuito de explorar algumas possibilidades de investigação da Independência como um nexo de ações de diferentes

\footnotetext{
${ }^{10}$ Ver FARIA JÚNIOR, Carlos de. O pensamento econômico de José da Silva Lisboa, Visconde de Cairu. (Tese) Doutorado em História, Universidade de São Paulo, São Paulo, 2008. KIRSCHNER, Tereza Cristina José da Silva Lisboa. Visconde de Cairu. Itinerários de um ilustrado luso-brasileiro. São Paulo: Alameda, 2009. ROCHA, Antonio Penalves. José da Silva Lisboa, visconde de Cairu. São Paulo: Ed. 34, 2001.

${ }^{11}$ DIAS, Maria Odila da Silva. Aspectos da Ilustração no Brasil. RIHGB, Rio de Janeiro, v.278, 1968. MAXWELL, Kenneth. A geração de 1790 e a idéia do império luso-brasileiro. In: Chocolate, piratas e outros malandros: ensaios tropicais. São Paulo, Paz \& Terra, 1999. NEVES, Guilherme Pereira das. Pálidas e oblíquas luzes: José Joaquim da Cunha de Azeredo Coutinho e a Análise sobre a justiça do comércio do resgate dos escravos. In: SILVA, Maria Beatriz Nizza da (Org.). Brasil: colonização e escravidão. Rio de Janeiro: Nova Fronteira, 2000. NOVAIS, Fernando Antonio. Portugal e Brasil na crise do antigo sistema colonial. São Paulo: Hucitec, 2005.

12 DIAS, Maria Odila da Silva. Aspectos da Ilustração no Brasil... op., cit., 1968. SILVA, Ana Rosa Cloclet da. Inventando a nação. SP, Hucitec, 2006. ARAUJO, Valdei Lopes. A experiência do tempo... op., cit.

${ }^{13}$ VIEIRA, Luis Otavio. Origens da imprensa no Brasil: estudo prosopográfico dos redatores e editores de periódicos publicados entre 1808 e 1831. (Dissertação) Mestrado em História, Universidade de São Paulo, São Paulo, 2019.
} 
gerações, e como essa distinção geracional pode ser percebida na ação e discursos políticos de diferentes indivíduos. Pretendemos apontar as diferenças etárias como elementos constituintes das trajetórias e ações individuais e também como limites fronteiriços entre elas, sem, no entanto, esquecer ou desprezar de outros fatores igualmente primordiais como posições sociais, redes de sociabilidade e projetos políticos. Buscaremos demonstrar a efetividade da História dos Conceitos e a forma como ela evidencia e analisa as experiências históricas como meio de identificar as quebras geracionais dentro do conjunto de nossos personagens. E com o auxílio das ferramentas teóricas desenvolvidas por Karl Mannheim - posição, conexão e unidades geracionais ao lidar com o tema das gerações, daremos contornos mais nítidos ao quadro multigeracional da Independência.

Os dados basilares para esse estudo, que doravante subsidiarão nossas reflexões - a saber: as datas de nascimento dos produtores de periódicos, as idades com que cada um começou a atuar na imprensa e as províncias de atuação - foram organizados na tabela a seguir. Daqui para frente, é ela que guiará o desenvolvimento de nossas ideias. Apesar de elencarmos 29 indivíduos, a análise recairá somente sobre alguns deles a fim de não extrapolar os limites de espaço desse trabalho.

Tabela 1. Produtores de periódicos, províncias de atuação, seus respectivos anos de nascimento e idade quando do início das atividades em periódicos ${ }^{14}$

\begin{tabular}{|l|c|c|c|}
\hline \multicolumn{1}{|c|}{ Produtores de periódicos } & $\begin{array}{c}\text { Província de } \\
\text { atuação }\end{array}$ & $\begin{array}{c}\text { Ano de } \\
\text { nasciment } \\
\mathbf{o}\end{array}$ & $\begin{array}{c}\text { Idade no } \\
\text { início da } \\
\text { atividade } \\
\text { em } \\
\text { periódicos }\end{array}$ \\
\hline José da Silva Lisboa (Visconde de Cairu) & Rio de Janeiro & 1756 & 65 \\
\hline Cipriano Barata & Bahia & 1762 & 61 \\
\hline
\end{tabular}

${ }^{14}$ Existem algumas lacunas na tabela. Não foram achadas as datas de nascimento de três personagens: Padre Tezinho, Manoel Rodrigues de Oliveira e Francisco de Paula Pérez. No entanto, ao menos para os dois últimos, foi possível estabelecer uma estimativa aproximada. Sabemos que Rodrigues de Oliveira formou-se médico em Coimbra no ano de 1799. MARQUES, Cesar Augusto. Diccionario historico-geographico da província do Maranhão. Maranhão: Typ. do Frias, 1870, vol 2, p.391. Um ano antes formouse na mesma instituição Hipólito da Costa. Já em 1801, diplomou-se pela Academia Real dos Guardas Marinha Manoel Ferreira de Araújo Guimarães. Hipólito e Guimarães nasceram respectivamente em 1774 e 1777. RIZZINI, Carlos. Hipólito da Costa e o Correio Braziliense. Cia Editora Nacional; São Paulo; 1957, p. 4. SARAIVA, Luis Manuel Ribeiro. Manoel Ferreira de Araújo Guimarães (1777-1838): From the Navy Royal Academy to the Royal Military Academy of Rio de Janeiro. Rev. Bras. de História da Matemática, v. 11, n. 21, São Paulo, 2011, p.84. Por aproximação, podemos supor que Rodrigues de Oliveira tenha nascido em algum momento na primeira metade da década de 1770 . Procedemos da mesma maneira em relação a Paula Pérez, formado em teologia pela Universidade de San Francisco Xavier, em 1804. GONZÁLEZ DEMURO, Wilson. Prensa periódica y circulación de ideas en la Provincia Oriental, entre el final de la dominación española y la independencia (1814-1825). Uruguay: Universidad de la Republica, 2013, p. 298. Em 1808, Gonçalves Ledo já estava a época de formar-se em leis em Coimbra, mas acabou por abandonar o curso por conta da morte do pai. BANDECCHI, Brasil. Ledo: pensamento e ação nas lutas da Independência. São Paulo: Parma, 1983, p. 98. Ledo nasceu em 1781, e, novamente utilizando Araújo Guimarães, nascido em 1777 e formado em 1801, como baliza, apontamos os últimos anos da década de 1770 como época aproximada do nascimento de Paula Pérez. 


\begin{tabular}{|l|c|c|c|}
\hline \multicolumn{1}{|c|}{ Produtores de periódicos } & $\begin{array}{c}\text { Província de } \\
\text { atuação }\end{array}$ & $\begin{array}{c}\text { Ano de } \\
\text { nasciment } \\
\text { o }\end{array}$ & $\begin{array}{c}\text { Idade no } \\
\text { início da } \\
\text { atividade } \\
\text { em } \\
\text { periódicos }\end{array}$ \\
\hline João Antônio de Garcia Abranches & Maranhão & 1769 & 56 \\
\hline Manuel Rodrigues de Oliveira & Maranhão & $\begin{array}{c}\text { década de } \\
1770\end{array}$ & - \\
\hline Hipólito da Costa & $\begin{array}{c}\text { Londres } \\
\text { (Inglaterra) }\end{array}$ & 1774 & 34 \\
\hline Francisco de Paula Pérez & Cisplatina & década de & 1770 \\
\hline Joaquim José da Silva Maia & Bahia & 1776 & 45 \\
\hline Manoel Ferreira de Araújo Guimarães & Rio de Janeiro & 1777 & 35 \\
\hline Padre Mororó & Ceará & 1778 & 46 \\
\hline Frei Caneca & Pernambuco & 1779 & 44 \\
\hline Cônego Januário da Cunha Barbosa & Rio de Janeiro & 1780 & 41 \\
\hline Frei Cirilo de Alameda y Brea & Cisplatina & 1781 & 30 \\
\hline Joaquim Gonçalves Ledo & Rio de Janeiro & 1781 & 40 \\
\hline Luis Augusto May & Rio de Janeiro & 1782 & 39 \\
\hline Cônego João Batista Gonçalves Campos & Pará & 1782 & 40 \\
\hline João Soares Lisboa & Rio de Janeiro & 1785 & 37 \\
\hline Diogo Soares da Silva de Bivar & Bahia & 1785 & 26 \\
\hline Padre Luiz Gonzaga Coelho Fleuri & Goiás & 1793 & 37 \\
\hline $\begin{array}{l}\text { Francisco Gê de Acaiaba Montezuma } \\
\text { (Visconde de Jequitinhonha) }\end{array}$ & Bahia & 1794 & 27 \\
\hline Bernardo Pereira de Vasconcelos & Minas Gerais & 1795 & 30 \\
\hline $\begin{array}{l}\text { José da Costa Carvalho (Marquês de } \\
\text { Monte Alegre) }\end{array}$ & São Paulo & 1796 & 31 \\
\hline Batista Caetano de Almeida & Minas Gerais & 1797 & 30 \\
\hline Libero Badaró & São Paulo & 1798 & 31 \\
\hline $\begin{array}{l}\text { Felipe Alberto Patroni Martins Maciel } \\
\text { Parente }\end{array}$ & Pará & 1798 & 23 \\
\hline Evaristo da Veiga & Rio de Janeiro & 1799 & 28 \\
\hline Vicente Ferreira Gomes & Pedro & 1805 & 22 \\
\hline Teófilo Ottoni & Pinas Gerais & 1807 & 23 \\
\hline Antônio Borges da Fonseca & 1808 & 20 \\
\hline Padre Tezinho & $\begin{array}{c}\text { Não } \\
\text { encontrado }\end{array}$ & - \\
\hline
\end{tabular}

Fonte: Elaborado pelo autor ${ }^{16}$.

\footnotetext{
${ }^{15}$ Abrimos a previsível exceção de incluir na lista Hipólito da Costa, um produtor de periódico em atividade fora dos limites dos territórios luso-americanos dada a importância do Correio Braziliense e da própria trajetória de seu redator para a história da Independência. Entre os aspectos que justificam sua inclusão, podemos destacar que este personagem foi um dos únicos portugue ses a produzir um periódico crítico e opinativo antes do final de 1820, ou seja, antes da queda da censura prévia, e um dos primeiros escritores públicos, senão o primeiro, a conceber e propagar a América portuguesa como uma unidade com interesses comuns. Ver JANCSÓ, István; SLEMIAN, Andrea. Um caso de patriotismo imperial. In: DINES, Alberto (Org.). Hipólito José da Costa e o Correio Braziliense. Estudos. São Paulo; Brasília: Imprensa Oficial do Estado; Correio Braziliense, 2002.

${ }^{16}$ As informações foram extraídas das seguintes obras KIRSCHNER, Tereza Cristina José da Silva Lisboa. Visconde de Cairu. Itinerários de um ilustrado luso-brasileiro. São Paulo: Alameda, 2009. MOREL, Marco. Cipriano Barata na sentinela da liberdade. Salvador, Academia de Letras da Bahia/Assembléia Legislativa do Estado da Bahia, 2001. ABRANCHES, Dunshee. Garcia de Abranches, o Censor (o Maranhão em 1822). São Paulo: Tipografia de Rothschild \& Co, 1922. MARQUES, Cesar Augusto. Dicionário histórico-geográfico da província do Maranhão..op. cit. RIZZINI, Carlos. Hipólito da Costa...op. cit. PEREIRA, Christiane Peres. A imparcialidade para doutrinar: os impressos de Joaquim José da Silva Maia no Brasil e em Portugal. (Dissetarção
} 


\section{GRUPOS ETÁRIOS E DESENVOLVIMENTO DA IMPRENSA}

A separação e agrupamentos do tempo em anos sob parâmetros estritamente matemáticos dificilmente comportam as durações dos fenômenos históricos ou colaboram para a sua análise. Entretanto, a fim de organizar em um primeiro momento nossa amostragem de personagens de acordo com um padrão etário, utilizamos os intervalos de décadas para dispor os 29 produtores de periódicos. Dessa maneira, temos um indivíduo $(3,45 \%)$ nascido na década de 1750 , dois $(6,9 \%)$ nascidos na década de 1760 , sete $(24,2 \%)$ na década de 1770 , outros sete $(24,2 \%)$ na década de 1800 , oito $(27,5 \%)$ na década de 1790 e, finalmente, três $(10,3 \%)$ nascidos nos primeiros dez anos do século XIX. Para o restante $(3,45 \%)$, padre José Antonio da Cruz Ferreira - mais conhecido como padre Tezinho -, não achamos nenhuma informação que pudesse indicar pistas sobre seu ano de nascimento.

Depurando um pouco mais essa organização preliminar, é possível separar todos os personagens - com exceção de Tezinho - em três grandes conjuntos, dois periféricos e de caráter residuais e um central e mais numeroso. Este último é composto pelos 22 indivíduos (75,8\%) nascidos entre 1770 e 1800. Já os residuais: um é formado pelos três nascidos $(10,3 \%)$ antes de 1770 e o outro pelos três nascidos (10,3\%) depois de 1800 . Assim, nos é permitido afirmar que a maior parte dos produtores de periódicos atuantes na Independência parece ter nascido entre 1770 e 1800.

Pensando na geração de 1790, representada em nossa seleção por Silva Lisboa,

\footnotetext{
de Mestrado), Rio de Janeiro, UFRRJ, 2013. TRENTIN, Paulo Henrique. Matemática no Brasil: as traduções de Manoel F. de Araújo Guimarães (1777-1938) das obras de Adrien Marie Legendre.. (Tese) Doutorado, Pontifícia Universidade Católica, São Paulo2011.MONTENEGRO, João Alfredo de Sousa. Padre Mororó: a revolução impressa. Fortaleza, Museu do Ceará, 2004. MELLO, Evaldo Cabral de. Frei Joaquim do Amor Divino Caneca. São Paulo, Editora 34, 2001. IPANEMA, Cybelle. Januário da Cunha Barbosa: para não esquecer. RIHGB - 158, n.394, jan./mar. 1997. GONZÁLEZ DEMURO, 2013. NAVARRO GARCIA, Jesus Raul. Actitudes politica de fr. Cirilo Alameda y Brea, arzobispo de Santiago de Cuba, Burgos y Toledo: su etapa cubana. Anales Toledanos, n 25, 1985. TAUNAY, Affonso de. Grandes vultos da Independência brasileira. São Paulo: Melhoramentos, 1922. VIANNA, Helio. Contribuição à história da imprensa brasileira (1812-1869). Rio de Janeiro: Instituto Nacional do Livra, 1945. BORGES, Ricardo. Vultos notáveis do Pará. Belém: Conselho Estadual da Cultura, 1970. FERREIRA, Paula Botafogo. Negócios, impressos e política: a trajetória pública de João Soares Lisboa (1800-1824). Campinas: Unicamp, 2017. BORGES, Humberto Crispim. O pacificador do norte: Luiz Gonzaga Camargo Fleuri. Goiás: CERNE, 1984. CASTRO JUNIOR, Sebastião Eugênio Ribeiro. Francisco Montezuma e os dilemas da mestiçagem e da cidadania na construção do Império do Brasil. (Dissertação) Mestrado em História, Universidade Federal Fluminense, Niterói, 2014. SOUSA, Octavio Tarquínio de. Bernardo Pereira de Vasconcellos e seu tempo. Rio de Janeiro: José Olympio, 1937. VIDIGAL, Geraldo. O Marquês de Monte Alegre: alvorecer de um estadista. São Paulo: Ibrasa, 1998. MACULAN, Carlos Eduardo. As luzes do tempo: Baptista Caetano de Almeida, projeto civilizacional e práticas políticas no Brasil pós-Independência (São João del-Rei, 1824-1839). (Dissertação) Mestrado em História, Universidade Federal de Juiz de Fora, Juiz de Fora, 2011. SILVEIRA, Argemiro. Alguns apontamentos biográficos de Libero Badaró. Rio de Janeiro: Typ. Universal de Laemmert \& C., 1890. SOUSA, Octavio Tarquínio. Evaristo da Veiga. Rio de Janeiro: Cia Nacional, 1939. RIBEIRO, Celia. O Jornalista Farroupilha: Vicente Ferreira Gomes 1805-1837. Porto-Alegre: Libretos, 2012. CHAGAS, P. P. Teófilo Ottoni: Ministro do povo. Belo Horizonte: Ed. Itatiaia, 1978. SILVA, Carolina Paes Barreto. A trajetória de O Repúblico no fim do Primeiro Reinado e na Regência: os discursos impressos de Antônio Borges da Fonseca sobre política imperial (18301837). (Dissertação) Mestrado em História, Universidade Federal Fluminense, Niterói, 2010.
} 
Hipólito da Costa e Araújo Guimarães, seus limites transcendem o primeiro grupo residual $(10,3 \%)$, mas não chegam à década de $1780(24,2 \%)^{17}$. Em termos etários, esse grupo poderia alcançar um índice de $34,5 \%$ de nossa amostragem, contra os $75,8 \%$ do grupo mais numeroso e os $51,6 \%$ desse mesmo grupo excetuando os nascidos na década de 1770. Nessa abordagem, a geração de 1790 não é o grupo majoritário entre os produtores de periódicos em ação durante a Independência. Por isso, em um primeiro momento, por alteridade, já seria verossímil tratar a Independência como um campo de dinâmicas multigeracionais. Mas lembramos que a data de nascimento e a faixa-etária não são os únicos definidores da geração de 1790: estar na rede de ilustrados a serviço da monarquia portuguesa para levar a cabo suas reformas era fundamental. Por isso, apesar de nascido em 1762, Cipriano Barata não era um componente da geração de 1790. De 1808 a 1820, como já mencionado, não é possível detectar uma opinião pública ainda que tipografias e impressos já circulassem na América portuguesa. Apesar da existência dos meios materiais que possibilitassem o surgimento da opinião pública ainda faltava a conjuntura política favorável, principalmente a liberdade de imprensa ${ }^{18}$. Poucos periódicos circulavam no Brasil e todos passavam pela censura prévia, características do Antigo Regime. A partir da Revolução do Porto, em 1820, a liberdade de imprensa é conquistada, abolindo-se, portanto, censura prévia. Como resultado, corroborado pelo gráfico a seguir, há - tomando o Rio de Janeiro como referencial - uma primeira explosão no número de periódicos publicados ${ }^{19}$.

Gráfico 1. Jornais publicados no Rio de Janeiro (1808 - 1840)

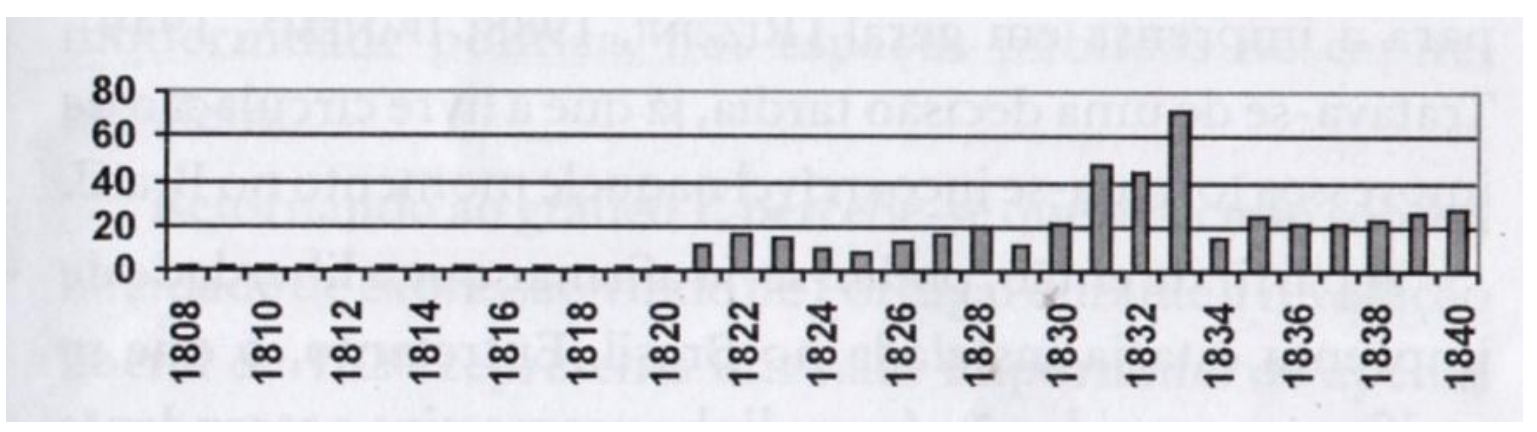

Fonte: MOREL; BARROS, 2003.

\footnotetext{
${ }^{17}$ Enfatizando que o ano, na denominação geração de 1790, não aponta exclusivamente para época de nascimento como fator definidor, mas também para o período de formação e atuação do grupo reformista.

18 Segundo Robert Darton, a tecnologia de impressão sofreu pouquíssimas mudanças entre a época de Gutenberg (século XV) e o século XIX. Disso, inferimos que a formação da opinião pública como instituição moderna, portanto, não dependia apenas da tecnologia material disponível, mas das transformações sociais e políticas adequadas para surgir, a partir do século XVIII. Ver DARNTON, 2010

${ }^{19}$ MOREL; BARROS, 2003, p. 23.
} 
Essa alta acompanha a difusão do vintismo na América portuguesa, o desenvolvimento da tensão entre a Corte no Rio de Janeiro e as Cortes de Lisboa, a ruptura entre Brasil e Portugal e os primeiros momentos da formação do Estado Nacional brasileiro. De 1823 a 1826 há uma sensível queda na quantidade de periódicos. Essa baixa segue a dissolução da Constituinte, a outorga da Carta de 1824 e a centralização do poder Executivo na Corte do Rio de Janeiro sem o contrapeso do Legislativo. Essa conjuntura parece ter permitido ao governo de D. Pedro I maior controle e repressão sobre as publicações e, logo, sobre a opinião pública.

Com a instalação do poder Legislativo, materializado na Câmara e no Senado, em 1826, o fomento dos debates parlamentares, articulações e embates, principalmente entre deputados, é acompanhado de uma revitalização dos periódicos e da opinião pública. E com exceção do ano de 1829 esse novo rompante segue em ascensão até a abdicação do imperador em 1831, ano em que a quantidade de títulos mais do que dobra em relação a 1830, insinuando alguma correlação entre a queda de D. Pedro I e a proliferação de periódicos.

Em suma, 1808, 1820 e 1826, principalmente os dois últimos anos, são os grandes marcos temporais iniciais de crescimento de periódicos durante a Independência. Aproximando-os com os dados da tabela 1, somos conduzidos a algumas associações.

Retomando a tabela inicial, entre os oito personagens nascidos na década de 1790, seis deles começaram a produzir periódicos próximos ao marco de 1826: Bernardo Pereira de Vasconcelos (O Universal - 7/1825 a 1842), Costa Carvalho (O Farol Paulistano 2/1827 a 6/1831), Batista Caetano de Almeida (O Astro de Minas - 11/1827 a 6/1839), Libero Badaró (O Observador Constitucional - 10/1829 a 11/1830), Evaristo da Veiga (A Aurora Fluminense - 12/1827 a 1835) e Padre Mororó (Diário do Governo do Ceará - 4 a 5/1824). De pronto, poderíamos inferir uma correlação entre os nascimentos da década de 1790 e os periódicos surgidos próximos a 1826, levando a crer que a ação política desses indivíduos estaria condicionada a ter início nessa conjuntura. Todavia, as duas exceções e mesmo a trajetória pregressa de alguns dos indivíduos acima citados desmentem esse suposto determinismo.

Felipe Patroni ( $O$ Paraense - 5 a 6/1822) e Francisco Montezuma (Diário Constitucional - 9/1821 a 8/1822; 3 a 4/1823), este último colega de Vasconcelos em Coimbra, tiveram atuação intensa na imprensa entre 1820 e 1823. Patroni foi preso e 
exilado, pelas autoridades provinciais paraenses, em 1822 e Montezuma expatriado no fim de 1823, com a dissolução da Constituinte onde era deputado ${ }^{20}$. Para ambos, mesmo nascidos em 1798 e 1794, respectivamente, a conjuntura que se inicia em 1826 foi estéril em termos de participação política, diferente da grande maioria de nossos personagens nascidos na mesma década.

Por outro lado, nesse mesmo grupo, os indivíduos com trajetórias frutíferas na cena política na conjuntura de 1826, como assinala a produção de periódicos, não necessariamente tiveram na imprensa as suas primeiras participações no contexto da Independência. Costa Carvalho, por exemplo, contemporâneo a Montezuma e Vasconcelos em Coimbra, teve tempos agitados na província de São Paulo entre 1820 e 1823. Nesse ínterim, bateu de frente com José Bonifácio e seus irmãos, lideranças da junta paulista, durante o evento conhecido como a Bernarda de Francisco Inácio ${ }^{21}$.

O início na produção de periódicos num período posterior a 1826 parece muito mais atrelado às condições materiais de São Paulo do que a data de nascimento de Costa Carvalho. Redigiu e editou $O$ Farol Paulistano a partir de 1827 , mesmo ano em que a primeira tipografia começou a funcionar na província ${ }^{22}$. Logo, antes da conjuntura de 1826, esse personagem já estava em plena ação no jogo político. Mas nessa época, seria muito difícil atuar na imprensa, uma vez que a tecnologia necessária simplesmente não existia em São Paulo. O único grupo cujas datas de nascimento, de fato, impediu a atuação entre 1820 e 1823 parece ter sido o dos nascidos após 1800 .

Após essas considerações acerca das possíveis relações entre ano de nascimento e possibilidades de participação em diferentes fases do desenvolvimento da imprensa no Brasil, passaremos agora a discutir os conceitos de geração e experiência propriamente ditos. Através da utilização segura de ambos, poderemos identificar elementos geracionais nas relações entre os anos de nascimento e as diferentes leituras e atuações dos produtores de periódicos na Independência.

\footnotetext{
${ }^{20}$ CASTRO JUNIOR, Sebastião Eugênio Ribeiro. Francisco Montezuma e os dilemas da mestiçagem e da cidadania no Império do Brasil (1820 - 1834). (Dissertação) Mestrado em História, Universidade Federal Fluminense, Niterói, 2014, p. 141. COELHO, Geraldo Mártires. Anarquistas, demagogos e dissidentes: a imprensa liberal do Pará de 1822. Bélem: Cejup, 1993 , p. 251.

21 "A Bernarda" de Francisco Inácio, ocorrida em maio de 1822 é sintomática para perceber a formação de forças políticas opostas em São Paulo. A disputa envolveu, de um lado, os Andradas, mais especificamente os irmãos José Bonifácio e Martim Francisco e seus aliados e, de outro, Francisco Inácio de Souza Queiróz e João Carlos de Augusto Oeynhausen. Um dos motivos da revolta foi “o despotismo dos Andradas". BORGES, Luiz Adriano Gonçalves. Aspectos econômicos da participação paulista no processo de independência. Almanack, v. 6, 2013, p. 67. VIDIGAL, Geraldo. O Marquês de Monte Alegre: alvorecer de um estadista. São Paulo: Ibrasa, 1998, p. 178

22 OLIVEIRA, Carlos Eduardo França. Poder local e palavra impressa: a dinâmica política em torno dos Conselhos Provinciais e da imprensa periódica em São Paulo, 1824- 1834 (Dissertação) Mestrado em História, Universidade de São Paulo, São Paulo, 2009, p. 176.
} 


\section{EXPERIÊNCIA E GERACÃO}

Entre os indivíduos com considerável diferença etária, a vivência, elaboração e acúmulo de experiência se dão de maneiras bastante diversas. Eventos e conjunturas são recepcionados e elaborados de modo variável de acordo com cada faixa-etária, "pois as experiências políticas são percebidas e processadas de maneira diferentes conforme a idade e a posição social" 23 . Além disso, pelo mesmo limite biológico imposto pela data de nascimento, nem todos os personagens elencados vivenciaram todas as conjunturas do processo de Independência, entre 1808 e 1831, havendo, portanto, variedade não só na recepção e elaboração de eventos comuns a todos, mas no próprio acúmulo de experiências. Cabe, a partir de agora, observar como essa heterogeneidade entre experiências, com base na faixa etária, se articula com a ação política dos produtores de periódicos.

Experiência, de acordo com Koselleck, remete ao "passado atual, aquele no qual acontecimentos foram incorporados e podem ser lembrados. Na experiência se fundem tanto a elaboração racional quanto as formas inconscientes de comportamento" ${ }^{24}$. Essa dupla qualidade, de vivência e elaboração narrativa, mantém elementos do passado no presente, inclusive orientando ações e construções de expectativas futuras. Sendo assim, se indivíduos de diferentes faixas-etárias vivenciam e/ou recepcionam, elaboram e narram experiências que podem transparecer em suas ações e projetos de maneira diversa isso implicaria a possibilidade de identificação entre diferentes gerações através da compreensão e manifestação dessa diversidade de experiências.

Buscando casos concretos, podemos novamente nos atentar para os extremos da Tabela 1. Em um polo, nomes como Silva Lisboa e Cipriano Barata; no outro, Borges da Fonseca e Teófilo Ottoni. Entre 1808 e 1831, a conjuntura comum de atividade pública entre os dois pares é a identificada com início em 1826, após a abertura da primeira legislatura seguida de um novo impulso na circulação de periódicos. Todavia, nesse momento, abria-se espaço para Ottoni e Borges da Fonseca se projetarem no debate público, enquanto Barata e Silva Lisboa já eram figuras bem conhecidas, veteranos nesse

\footnotetext{
${ }^{23}$ KOSELLECK, Reinhart. Estratos do tempo: estudos sobre história. Rio de Janeiro: Contraponto: Editora PUC-Rio, 2014 , p. 35. ${ }^{24}$ KOSELLECK, 2014, p. 309.
} 
cenário. Durante a Conjuração Baiana, em 1798, o primeiro esteve entre os acusados do levante, enquanto o segundo já despontava como ilustrado da confiança de Sousa Coutinho $^{25}$. Isso implica vivência, de ambos, da crise colonial portuguesa sob a identificação de súditos portugueses. Por outro lado, Ottoni e Borges da Fonseca já eram cidadãos brasileiros desde que começaram a dar seus primeiros passos publicamente. Não obstante, igualmente terão suas trajetórias muito ligadas ao Segundo Reinado, fase da história brasileira posterior às mortes de Silva Lisboa e Barata ${ }^{26}$.

Sendo assim, os dois pares diferem quando os tópicos são vivência, acúmulo e elaboração de experiências. Para representar essa diacronia, uma possibilidade é identificá-los como pertencentes a diferentes gerações atribuindo a esse termo a capacidade de fracionar e separar o tempo histórico. Uma vez que Silva Lisboa é apontado por parte da historiografia como um grande representante da geração de 1790 , isso se estenderia também a Barata, com base na aproximação etária de ambos? Não, pois parte da definição da geração de 1790 está atrelada a um grupo reformista orientado por Sousa Coutinho, o que não é o caso de Barata. Então, qual é o limite e a abrangência do termo geração? Ele abarca a dimensão temporal e/ou a dimensão social e política?

Uma das críticas à ideia de caracterização da geração de 1790 é justamente a falta de uma definição clara em relação ao termo ${ }^{27}$. Para podermos operar com mais segurança, buscamos na obra de Karl Mannheim as bases e possibilidades da categoria de geração, pela sua preocupação com a diacronia do tempo histórico e a permanência de sua atualidade dentro da Sociologia ${ }^{28}$. Para ele,

[...] la conexión generacional no es, ante todo, otra cosa que una modalidad específica de posición de igualdad dentro del ámbito históricosocial, debida a la proximidade de los años de nacimiento (...), la posición generacional se puede determinar a partir de ciertos momentos vitales basados en los datos naturales de la mudanza de las generaciones - que sugieren a los individuos afectados por ellos determinadas formas de

\footnotetext{
${ }^{25}$ KIRSCHNER, Tereza Cristina. José da Silva Lisboa. Visconde de Cairu... op. cit. MOREL, Marco. Cipriano Barata na Sentinela da Liberdade. Salvador: Academia de Letras da Bahia; Assembléia Legislativa do Estado da Bahia, 2001, p. 63.

${ }^{26}$ RICCI, Maria Lúcia de Souza Rangel. A atuação política de um publicista: Antônio Borges da Fonseca. São Paulo: PUC Campinas, 1995. MIRANDA, Leonardo Souza de Araújo. A Democracia da Gravata Lavada: Teófilo Ottoni, vida, identidade política, espaço público e republicanismo entre (1826-1842). (Dissertação) Mestrado em História, Universidade Federal de Minas Gerais, Belo Horizonte, 2008

${ }^{27}$ FALCON, Francisco Calazans; KANTOR, Irís. Geração de 1790. In: VAINFAS, Ronaldo; NEVES, Lúcia Maria Bastos Pereira das. (Org.). Dicionário do Brasil Joanino (1808-1821). Rio de Janeiro: Objetiva, 2008, p.181.

${ }^{28}$ WELLER, Wivian. A atualidade do conceito de gerações de Karl Mannheim. Sociedade e Estado, v. 25, 2010 , p.220.
} 
vivencia y pensamento. ${ }^{29}$

O nascimento, portanto, marca uma posição geracional que, dependendo da conjuntura e dos eventos, pode ativar uma conexão geracional estabelecendo entre os indivíduos com posições geracionais semelhantes a vivência e elaboração de experiência acerca dos mesmos fenômenos históricos. Todavia, partilhar a vivência e experiências sobre determinados processos e acontecimentos não aloca automaticamente os indivíduos nos mesmos grupos de interesse, tampouco assegura afinidade social e/ou política como no caso da chamada geração de 1790 , na qual seus componentes estavam unidos pelo compromisso com as reformas ilustradas do império português. Esse grupo concreto e com interesses comuns caberia no modelo proposto por Mannheim como uma unidade geracional $^{30}$. Logo, Barata e Silva Lisboa, em relação a 1798, por exemplo, possuíam posições geracionais semelhantes, dada pela proximidade das datas de nascimento. A semelhança das posições geracionais, por sua vez, se desenvolveu para uma conexão geracional através da observação, vivência e participação de cada um na Conjuração Baiana. Todavia, em nenhum momento os dois se encontraram nos mesmos grupos políticos. Portanto, estiveram em unidades geracionais distintas e mesmo antagônicas entre si, com Barata ao lado dos revoltosos e Silva Lisboa como um burocrata e ilustrado a serviço do Estado.

Já em relação a Ottoni e Borges da Fonseca, novas posições geracionais implicam em "un nuevo acceso al bien cultural acumulado" socialmente ${ }^{31}$. Parte das experiências vivenciadas por Barata e Silva Lisboa se tornou uma porção de um bem cultural para os outros dois - Ottoni e Borges da Fonseca - cujos relatos também são passíveis de (re)elaboração. Portanto, a diferença de posição geracional pode implicar diferentes maneiras de experiência e acumulação dela dentro do devir histórico, indicando uma possível quebra geracional.

Dessa forma, está claro que Mannheim recusou a identificação de gerações com base somente nas datas de nascimento (posição geracional), ressaltando que a conexão depende de conjunturas e eventos históricos comuns. Assim, os impulsos sociais tornamse indispensáveis

\footnotetext{
${ }^{29}$ MANNHEIM, Karl. El problema de las geraciones. REIS, $\mathrm{n}^{\circ}$ 62, 1993, p.210.

${ }^{30}$ MANNHEIM, 1993, p. 211.

${ }^{31}$ MANNHEIM, 1993, p. 211.
} 
Cuando sucede algo de ese estilo tendríamos que hablar, más bien, de la activación de una potencialidad de la posición que estaba dormida. Parece probable que la intensidad de la activación esté conectada con la velocidad de la dinámica social. Si las revoluciones socioespirituales introducen un tiempo que acelere la transformación de las disposiciones hasta el punto de que no sea ya posible una modificación latente y continua de las formas de la vivencia, del pensamiento y de la configuración, ocurre entonces que los nuevos puntos de partida cristalizan en alguna parte, con la figura de un impulso que se destaca como algo nuevo y de una nueva unidad que da forma. En estas ocasiones hablamos de un nuevo estilo generacional, de una nueva entelequia generacional. ${ }^{32}$

A quebra geracional, portanto, não é definida por uma matemática fixa levando em conta apenas datas de nascimento. Ela se apoia fortemente em experiências históricas diversas, que dependem por sua vez da velocidade de alteração de conjunturas e eventos. "Hay capacidades que sólo pueden llegar a realizarse mediante la efectividad de los nuevos nacimientos, como son la de disponerse de nuevo a partir de la nueva sustancia vital, o la de formar un nuevo destino, nuevas formas de expectativas preconfiguradoras a partir de un nuevo contexto de experiência"33.

A mudança geracional, sendo assim, pode ser percebida em novas formas de vivência e pensamento, ou seja, novas experiências, que por sua vez ensejam e orientam novas expectativas e, consequentemente, novos projetos futuros.

Experiência e expectativa são duas categorias centrais para Koselleck e sua história dos conceitos. De acordo com o historiador alemão, a utilização desse par permite a investigação do tempo histórico, na medida em que, de maneira integrada, experiência e expectativa sempre orientam ações e discursos políticos. Logo, diferentes espaços de experiência conformam diferentes horizontes de expectativa, apontando diversidade geracional $^{34}$. E é justamente através da utilização dos conceitos que essa mudança pode ser percebida, pois "conceptos vendrían a ser algo así como concentrados de experiencia histórica y, al mismo tiempo, dispositivos de anticipación de las experiencias posibles" ${ }^{35}$.

\footnotetext{
${ }^{32}$ MANNHEIM, 1993, p. 228.

${ }^{33}$ MANNHEIM, 1993, p. 215.

${ }^{34}$ KOSELLECK, 1999, p. 308.

35 SEBASTIÁN, Javier Fernández. Hacia una historia Atlântica de los conceptos políticos. In: SEBASTIÁN, Javier Fernández (dir.), Diccionario político y social del mundo ibero-americano: La era de las revoluciones, 1750-1850. [Iberconceptos I], Madrid, Fundación Carolina / CEPC, 2009, p.27.
} 
Expressos em palavras, entre outras maneiras, torna-se viável investigar o modo como os produtores de periódicos se valem de conceitos, portas de entradas para o espaço de experiência e horizonte de expectativa desses indivíduos, e, também, de aproximações ou distanciamentos geracionais.

Propício para essa análise é o processo de Independência, pois sua sucessão de conjunturas denota a aceleração do tempo referida por Mannheim como fecunda para a revelação de quebras geracionais. Entre a migração da Corte para o Rio de Janeiro, a Revolução do Porto, o processo de ruptura política com Portugal e finalmente a reorganização de forças no Estado imperial brasileiro marcada pela abdicação de D. Pedro I, esse período oferece uma aceleração até então nunca antes vista do tempo histórico na América portuguesa, ensejando um acúmulo de experiência vertiginoso e, consequentemente, uma sucessão de projetos e expectativas ${ }^{36}$.

Não obstante, as fronteiras do território luso-americano, não significaram uma barreira rígida entre a nova sede do império e as convulsões e as revoluções de independência dos novos estados hispânicos. Pelo contrário, a proximidade dos processos revolucionários da América espanhola integrou os territórios portugueses em um mesmo espaço de experiência, tornando os eventos políticos na ibero-América indicadores de aceleração do tempo histórico e eventos que passariam a conformar os prognósticos e expectativas dos atores políticos que ali viviam ${ }^{37}$.

São todos acontecimentos dotados de grande ineditismo e que trazem em si a manifestação de uma grande crise. Na esteira dessa aceleração do tempo irrompe uma alteração contínua de espaços de experiência e horizontes de expectativas. Dessa maneira, o modo de elaboração dessas sucessivas experiências se dá, em parte, de formas distintas de acordo com os limites biológicos de tempo de vida para os indivíduos e com suas diversas perspectivas de futuro.

\section{CONCEITO E DIVERSIDADE GERACIONAL}

\footnotetext{
${ }^{36}$ JANCSÓ, István; PIMENTA, João Paulo Garrido. Peças de um mosaico (apontamentos para o estudo da emergência da identidade nacional brasileira. In: MOTA, Carlos Guilherme. (Org.). Viagem Incompleta 1500-2000 - A experiências Brasileira. São Paulo: SENAC São Paulo Editora, 2000.

${ }^{37}$ PIMENTA, João Paulo. A Independência do Brasil e a experiência hispano-americana (1808-1822). São Paulo: Hucitec, 2015. PIMENTA, João Paulo. Tempos e espaços das independências: a inserção do Brasil no mundo ocidental (c.1780 -c.1830), São Paulo: USP, 2012.
} 
Silva Lisboa foi um prolixo produtor de periódicos entre 1808 e 1831. Em um de seus primeiros títulos, O Conciliador do Reino Unido, em março de 1821, quando já ultrapassava os 60 anos de idade, apontava que:

[...] o propósito desta Folha Literária o conciliar, e jamais desunir, os ânimos e os interesses dos naturais e habitantes da Monarquia Lusitana; convindo por isso, quanto posso e devo, bem dirigir a Opinião Pública, a fim de atalhar os desacertos populares, e as efervescências frenéticas, de alguns compatriotas, mais zelosos que discretos, e que antes preferem arder que luzir.

Além disso:

[...] depois que rebentou no fim do Século passado o Vulcão Revolucionário da França (cuja hórrida catástrofe foi acelerada por senão ter feito em oportunas épocas serena revisão das Leis antiquadas, e prudente mudança das Instituições incompatíveis com as luzes das ciências sobre a melhora do Regimento Civil), tendo quase todas as Nações [...] depois da Paz Geral adotado a Liberal Constituição da Grã-Bretanha [...] era impossível que a Briosa Nação Portuguesa [...] permanecesse estacionária ${ }^{38}$.

Décadas depois, no ano de 1860, com Silva Lisboa há muito falecido, saiu a público a Circular dedicada aos srs. eleitores de senadores pela província de Minas Gerais, de Ottoni. Essa publicação visava projetar a figura de Ottoni na província a fim de angariar votos para ocupar uma cadeira no Senado. Posto ocupado por Silva Lisboa já em 1831, quando Ottoni figurava como parte da articulação de oposição contra o governo de D. Pedro I redigindo o periódico Sentinela do Serro. Em parte da Circular, o autor rememorou justamente o impacto da abdicação do imperador, em 1831, na Vila do Príncipe, em Minas Gerais.

Instantaneamente a cidade iluminou-se, bandas de música acompanhavam a guarda cívica e a população em massa, que até o romper do dia

${ }^{38}$ O Conciliador do Reino Unido $\mathrm{n}^{\circ} 4,3$ de março de 1821. 
percorreram as ruas, cantando hinos patrióticos, entre vivas à liberdade, à revolução de 7 de abril, ao redator do Sentinella do Serro etc, etc.... Nessa noite, sem a enérgica e generosa intervenção do redator da Sentinella do Serro, os primeiros ímpetos do povo triunfante teriam sido fatais a alguns poucos desafetos à nova ordem de coisas e ao mesmo tempo pessoas inofensivas. Entre hinos e vivas, repetiam-se com furor grito de guerra dos dias antecedentes: - Abaixo o tirano! Morram os Portugueses! - Morra o Japiassu! Como designavam o ouvidor da Comarca, Desembargador Antônio José Vicente da Fonseca [...] que por efeito das suas convicções tinha desaprovado o nosso movimento revolucionário. A exacerbação dos espíritos prognosticava cenas horrorosas, mas minha influência [...] era imensa. À porta do ouvidor, depois de uma cena tumultuosa, pude conseguir silêncio e atenção. Arenguei ao povo, pregando e exigindo moderação e generosidade e pedindo que - os morras - somente ecoassem contra o tirano, e que não manchássemos com excessos criminosos a bela vitória que nossos irmãos fluminenses acabavam de ganhar. Minha palavra tinha autoridade, e coube-me a glória de salvar um magistrado honrado e os portugueses que residiam na povoação. ${ }^{39}$

Diversos elementos apontam para conjunturas distintas evocadas no texto de cada autor. Silva Lisboa se dirige a população do Império Português; já nas linhas redigidas por Ottoni, o termo português adquire conotação pejorativa, identificado com o eximperador e sua base de apoio em antagonismo com o Império Brasileiro. No impresso de 1821, há um claro entendimento do autor de que ele deve tomar para si a condução do debate público, precavendo-se de que o constitucionalismo português não pendesse para os rumos revolucionários da França. Assim, a revolução apresenta-se como uma possível degeneração futura a ser evitada a todo custo, havendo como exemplos práticos, além da França, a contemporânea América Espanhola de início da década de 1820. É certo que temor semelhante também está presente nas palavras de Ottoni, sobretudo se advindo da falta de moderação das massas; mas no trecho citado, o político afirma que ele mesmo, devido sua influência e liderança entre o povo, impediu o pior de acontecer. E, mais importante, em Ottoni, ao contrário de Silva Lisboa, a degeneração violenta não se confunde com a revolução em si.

\footnotetext{
${ }^{39}$ OTTONI, Teófilo. Circular dedicada aos srs. eleitores de senadores pela província de Minas Gerais. Rio de Janeiro: Typhografia do Correio Mercantil, 1860, p. 16.
} 
Entre os dois produtores de periódicos, escrevendo em momentos distintos, certos termos encontram semântica e valoração bem semelhantes. Moderação figura como valor fundamental e imprescindível. Em contrapartida, revolução passa por modificações entre um e outro.

A alteração observada no conceito de revolução entre indivíduos tão distantes em termos de posição geracional - mais de 50 anos entre o nascimento de um e outro - é um bom indicativo para perscrutar se essa mudança se relaciona com mudanças geracionais, ligadas, como vimos, à acumulação distinta de experiências. István Jancsó desenvolveu um modelo de "ciclo de acumulação de experiência histórica" para a antiga América portuguesa entre os fins do século XVIII e a formação do Estado Nacional brasileiro no início do século XIX. Conforme o autor, há quatro ciclos:

O primeiro foi o da revisão/contestação das relações metrópole-colônia a partir da crítica política prática de aspectos do estatuto colonial, cobrindo o último quartel do século XVIII. O segundo ciclo, de matriz prática e doutrinariamente conservadora, se dá nos marcos da legitimidade dinástica e repousa sobre o resgate quase anacrônico do direito tradicional ibérico, aliado à revisão da ideia de Império, numa releitura colonial. Somente o terceiro ciclo configura a ruptura da dependência política como eixo articulador das ações políticas, enquanto o quarto movimento é, para o conjunto, o da reconstrução das relações internas de poder resultantes da reciclagem ou supressão da forma anterior ${ }^{40}$

Aplicando o modelo às trajetórias individuais de Silva Lisboa e Ottoni, temos que o primeiro participou e vivenciou pública e politicamente os quatro ciclos, enquanto o segundo, só o último ${ }^{41}$. Isso pelo claro limite biológico representado pelas diferentes posições geracionais. A própria Circular de Ottoni revela o modo indireto como o autor vivenciou os eventos de 1821, momento em que um já quase sexagenário Silva Lisboa estava na vanguarda do debate público redigindo e editando o Conciliador do Reino Unido. O produtor de periódicos mineiro tinha "apenas 13 anos de idade quando em 1821 ecoou pelo Brasil o grito da liberdade [...] foi uma faísca elétrica que, passando através

${ }^{40}$ JANCSÓ, István. A Construção dos Estados Nacionais Na América Latina - Apontamentos Para O Estudo do Império Como Projeto. In: LAPA, José Roberto do Amaral; SZMRECSÁNYI, Tamás. (Org.). História econômica da Independência e do Império. São paulo: Hucitec, 1996, p.6.

${ }^{41}$ Ver ROCHA, 2001. 
do espírito patriótico de meu pai, o Sr. Jorge Benedicto Ottoni, abrasou-me também a jovem imaginação" ${ }^{\prime 2}$.

Assim, em 1821, Silva Lisboa não só experienciava diretamente os eventos e a conjuntura de crescente polarização de interesses entre Brasil e Portugal como era um de seus protagonistas. Já Ottoni, recebia essa experiência de forma indireta, tendo o pai como um anteparo, devida a sua tenra idade. Os dois, possuindo cada qual um acúmulo de experiência diferente, só iriam a começar partilhar o mesmo palco de ação política durante os anos finais do Primeiro Reinado.

Toda essa disparidade entre as duas trajetórias, bem como as experiências relativas a cada uma é ainda mais acentuada ao observarmos o desenvolvimento conceitual de revolução no mundo luso-americano e brasileiro. Ainda no século XVIII, de acordo com Pimenta e Fanni, "nos discursos reformistas, revolução é termo preterido, em favor de outros como reforma, adiantamento, melhoramento e progresso" 43 . Políticas reformistas que como vimos eram ambiente familiar a Silva Lisboa e à geração de 1790. Todavia, ainda na Conjuração Baiana de 1798, evento em que Barata - vinculado a Silva Lisboa pela conexão geracional - teve participação, a homogeneidade negativa do conceito já começava a ceder. E nas produções textuais dos conjurados, a palavra revolução se aproximava semanticamente a outras como felicidade e liberdade ${ }^{44}$. A politização do conceito e, consequentemente, sua disputa semântica se acirrou ainda mais com a Revolução Pernambucana de 1817.

Nesse rumo de revalorização do conceito, em 1822, mesmo quadros e grupos mais conservadores passaram a utilizar revolução para elaborar a experiência da ruptura política entre Brasil e Portugal: uma revolução ordeira e conservadora, uma nova possibilidade descartada no texto de Silva Lisboa em $1821^{45}$. A partir daí o conceito "se encontrava pronto para adentrar com força na história do novo país, onde fincaria raízes profundas pelas quais a nova nação representaria seu passado e a si mesma,

\footnotetext{
42 OTTONI, 1860, p.2.

${ }^{43}$ PIMENTA, João Paulo; FANNI, Rafael. Revolución en Brasil: la historia de un concepto, un concepto en la historia (siglos XVIII$\mathrm{XXI}$ ). In: Fabio Wasserman. El mundo en movimiento: el concepto de revolución en Iberoamérica y el Atlántico norte(siglos XVIIXX). Buenos Aires: Miño y Dávila, 2019. Ver também MOTA, Carlos Guilherme. Idéia de revolução no Brasil: 1789-1801. São Paulo: Editora Ática, 1996.

${ }^{44}$ PIMENTA; FANNI, 2019.

${ }^{45}$ PIMENTA; FANNI, 2019. Posteriormente, em 1827, com sua obra acerca da Independência, Silva Lisboa encampou com alguma relutância a ideia de uma revolução bem sucedida para o período entre 1820 e 1822 . Com relutância, pois para ele, a revolução só se deu de forma ordeira por D. Pedro tomá-la das mãos de seus maquinadores e arquitetos e dar-lhe curso. Nesse viés, a revolução ainda nociva em sua origem, foi regenerada "especialmente pela comparência do Príncipe Real no Governo do Estado para dirigir a Revolução no Rio de Janeiro que infalivelmente estava a rebentar por maquinações de Demagogos e resolução dos Militares". Ver LISBOA, José da Silva. Historia dos principais successos politicos do Imperio do Brasil dedicada ao senhor D. Pedro I. Rio de Janeiro: Typ. Imperial e Nacional, 1827-1830, p. 58.
} 
condicionando até mesmo tradições eruditas e acadêmicas"46.

Do período das reformas ilustradas, quando o conceito era unanimemente negativo, passando por sua politização, disputa semântica até a sua recepção como válido em setores conservadores para descrever a Independência, foi a acumulação de experiência política que ensejou as alterações de significados para o termo revolução. Não obstante, a escrita de Silva Lisboa não acompanhou esse desenvolvimento conceitual em sua plenitude. Assim como em 1821, nos anos subsequentes, o ilustrado permanece associando revolução majoritariamente a desordem, mudanças bruscas e levantes violentos, tendo como principal referência a Revolução Francesa. Isso é perceptível, por exemplo, em seu confronto com Frei Caneca. Os dois se enfrentaram por meio de impressos em 1824. Nas linhas do Rebate brasileiro contra o Thyfis Pernambucano, Silva Lisboa respondia a publicação de Caneca: “é do dever patriótico interpor apelo à honra brasileira a fim de que [...] se destroncar a hidra do jacobinismo, que ousa de colo alçado insurgir com o espectro do federalismo"47.

Em 1828, debatendo na imprensa sobre se a soberania do povo superava ou não a soberania do imperador, Silva Lisboa novamente respondeu a seus antagonistas: "todos os amantes da Ordem Civil, são unânimes e uníssonos em reconhecer e afirmar, que a Monarquia da França foi derrubada pelos Trombeteiros do Princípio Anárquico, que a Astréa e sua Correspondência apregoa - a Soberania reside na Nação "48.

A imutabilidade da França revolucionária como parâmetro principal na retórica de Silva Lisboa, quando o conceito de revolução perpassava o tema do discurso, não escapou à percepção de seus pares na vida política. Já em 1832, José de Alencar declarava sobre seu colega de Senado: "sua literatura, posto que vasta, quando muito poderia ser própria para o século passado até 1789 , para agora de certo, não é muito própria"49.

Na mesma posição geracional de Silva Lisboa, compartilhando com este, como já demonstrado, também uma conexão geracional, mas em completa oposição quando se trata de unidades geracionais, estava Barata, apenas seis anos mais novo que o rival. Para o redator do icônico Sentinela da Liberdade, assim como para o notório conservador, a Revolução Francesa foi ricamente vivenciada e acompanhada contemporaneamente. Mais do que isso, para os envolvidos na Conjuração Baiana de 1798 - caso de Barata -,

\footnotetext{
${ }^{46}$ PIMENTA; FANNI, 2019.

${ }^{47}$ Rebate brasileiro contra o Thyfis Pernambucano. Rio de Janeiro: Typographia Nacional, 1824. BN - Obras Raras - OR-00518 [11].

${ }^{48}$ Honra do Brasil desafrontada de insultos da Astréa espadaxina $\mathrm{n}^{\circ} 8$, maio de 1828.

${ }^{49}$ Anais do Senado Federal, sessão de 23 de maio de 1832, v.1, p.114.
} 
havia uma real expectativa de cruzamento entre seus destinos e os dos revolucionários franceses. Segundo Morel, os depoimentos de Barata nos autos indicavam uma forte perspectiva de auxílio das tropas revolucionárias francesas aos revoltosos baienses ${ }^{50}$.

O que era expectativa em 1798 se sedimentou chamariz na elaboração de experiências nos anos seguintes. Em confronto impresso com o Padre José Joaquim Sobreira, representante cearense na Constituinte de 1823, acerca da autonomia das províncias em relação a um novo poder central, Barata escreveu: “em uma Revolução o povo reassume a sua autoridade e os seus Direitos imprescritíveis, e destrói o seu Governo, aniquila os reis, as Leis e tudo velho para criar tudo novo" ${ }^{\text {. }}$. Conforme Morel, uma herança direta de retórica e de princípios da Revolução Francesa ${ }^{52}$. Considerando, portanto, a Independência uma revolução, e o momento como propício para suplantar a velha ordem sem maiores restrições, Barata representa posicionamento diametralmente oposto ao de Silva Lisboa. Mas tal alteridade só se verifica em relação a unidades geracionais, sendo essa oposição somente possível por ambos partilharem de uma conexão geracional cuja principal referência era a Revolução Francesa.

Nas palavras de Mannheim, "alguien es viejo cuan vive en el contexto de una experiencia específica que él mismo obtuvo y que funciona como una preconfiguración, por cuyo medio cualquier nuev experiência recibe de antemano, y hasta cierto punto, la forma y el lugar que se le asignan" ${ }^{53}$. Sobre o processo de envelhecimento, Koselleck pontua que "podemos caracterizar o envelhecimento pela diminuição da capacidade de se surpreender. Quanto maior tiver sido o acúmulo interiorizado de surpresas possíveis, menor será a capacidade de surpreender-se, tão própria dos jovens" ${ }^{\text {"5 }}$. Assim, todas as experiências, daí em diante, que dialogam com o conceito de revolução, tendem a serem valorizadas por Silva Lisboa e Barata tendo como parâmetro de destaque a experiência anterior da Revolução Francesa.

A idade de Silva Lisboa também não passou batida como alvo para seus rivais. Acentuando a diferença entre suas posições geracionais, Ottoni, no Sentinela do Serro, aproximou o posicionamento político de seu antagonista à sua velhice. Na ocasião, Ottoni defendia o poder Legislativo das críticas de Silva Lisboa: "que o caduco Silva Lisboa

\footnotetext{
${ }^{50}$ MOREL, 2001, p. 63. MATTOSO, Katia Queiroz, Presença francesa no Movimento Democrático Baiano de 1798, Salvador, Itapuã, 1969.

${ }^{51}$ MOREL, Marco. Sentinela da Liberdade e outros escritos (1811-1835). São Paulo: Edusp, 2009, p. 291

52 MOREL, 2001, p. 341.

${ }^{53}$ MANNHEIM, 1993, p. 215.

${ }^{54}$ KOSELLECK, 2014, p. 24
} 
insultasse com tanta injustiça a Assembleia Constituinte não nos admira"

Em relação ao conceito de revolução, Ottoni, já em 1829, nos tempos de Sentinela do Serro, trazia como principal referência não a Revolução Francesa, como Silva Lisboa e Barata, mas a própria ruptura entre Brasil e Portugal. A experiência elaborada a partir desse evento, tomando-o como uma revolução positiva mesmo entre grupos conservadores, oferecia ao conceito maiores possibilidades e aceitação. Na epígrafe da Sentinela do Serro, o primeiro de Ottoni, uma citação de Thomas Jefferson "conclamava os leitores a usar o direito de revolução como saída em caso de governos despóticos"; dizia, ainda, que "o fim de toda associação política é a conservação dos direitos naturais e imprescindíveis do homem; estes direitos são a liberdade, a segurança, a propriedade e a resistência à opressão" 56 .

Poucos meses após a abdicação de D. Pedro I era possível ler no mesmo periódico:

Quando os servis nos atacam ou quando é preciso desarmá-los para evitar o ataque, é lícito, ou antes, é rigoroso dever dos filhos da Pátria [...] voarem ao campo de batalha, e fazerem aí, (mas somente aí) cruenta guerra aos inimigos da liberdade; mas quando a vitória declarou-se por nós, quando a força está da nossa parte é uma vileza, é uma indignidade abusar da fraqueza dos vencidos para espancá-los [...] mas não foi essa a conduta dos briosos fluminenses [...] no dia 7 de abril [...]. Neste combate virtuoso nunca se ousam mostrar-se os sanguinários ambiciosos, sempre fracos e covarde [...] Robespierre escondeu-se quando os verdadeiros republicanos [...] atacaram o palácio de Luiz XVI; ganha a batalha, eis o monstro surgindo para vir fazer os massacres do 2 e 5 de setembro. Temos quase certeza que isto não sucederá entre nós; os liberais não consentirão ainda que apareçam no Brasil Robespierres ${ }^{57}$.

O conceito de revolução, associado ao 7 de abril, apresenta-se distinto para Ottoni do que era para Silva Lisboa. Não há mais um juízo depreciativo instantâneo ao conceito. Apesar da revolução, conforme o produtor de periódicos, poder ser degenerada em massacres levados a cabo pelos sanguinários, a princípio essa não é uma sina inescapável. A França, mais especificamente a fase jacobina representada por Robespierre, de forma

\footnotetext{
${ }^{55}$ Astro de Minas $\mathrm{n}^{\circ} 451,9$ de outubro de 1830.

${ }^{56}$ MIRANDA, 2008, p. 167.

${ }^{57}$ Aurora Fluminense $\mathrm{n}^{\circ} 495,15$ de junho de 1831.
} 
semelhante ao que ocorre nos discursos de Silva Lisboa, figura como exemplo negativo. O problema não reside mais na Revolução Francesa, mas especificamente no terror jacobino, e na atuação de figuras como Robespierre. Mesmo república/republicanos, termos majoritariamente rechaçados nos primeiros anos do processo de Independência, ganham agora acenos e usos positivos. Inclusive a experiência francesa ainda conectada ao conceito é sobrepujada pela experiência recente do próprio 7 de abril como exemplo bem sucedido de revolução. Ainda um processo em aberto, Ottoni não crê em sua degeneração. A França consta como exemplo ocorrido há mais de quarenta anos, o que para Ottoni representa uma lição dentro da História passada a ele como bem sociocultural que ele não vivenciou, diferente do 7 de abril, o qual viveu e no qual atuou diretamente.

Como já dito, mesmo setores mais conservadores e ligados à Corte no Rio de Janeiro, e, assim, mais próximos a Silva Lisboa, também internalizaram essa nova concepção de revolução. Exemplo foi o Diário do Governo, folha oficial governista, que já em 1823 apresentou a Independência como uma positiva revolução moderada e conservadora $^{58}$. Com o aumento do leque de possibilidades dentro da polissemia do conceito, grupos estritamente contrários a convulsões sociais e refratários em relação à participação popular na política passavam a se utilizar do termo revolução, não mais condicionado por uma semântica negativa e degenerativa. Movimentos supostamente bem guiados e ordeiros, na concepção desses grupos, agora também poderiam ser designados pelo termo.

Evaristo da Veiga, responsável pela Aurora Fluminense, figura como exemplo de um típico antirrevolucionário que internalizou a transformação conceitual de revolução ${ }^{59}$. Além disso, em termos de posição geracional, está entre Silva Lisboa e Ottoni, representando o subgrupo mais numeroso de nossos personagens: os nascidos entre 1770 e 1800. Em 1828, o autodenominado "moderado" via a si mesmo como estando entre um grupo absolutista e outro exaltado. Sobre esse último, aproximava-o dos riscos da desordem e da anarquia; temia que seus integrantes se infiltrassem na cena política sob o disfarce de moderados e ali perpetrassem seus projetos radicais. Com isso em mente, Evaristo afirmava que "a instituição das Câmaras deliberantes é muito vantajosa, mas que é preciso acautelar os excessos, a que facilmente propendem; e logo com a história da

\footnotetext{
${ }^{58}$ PIMENTA; FANNI, 2019.

${ }^{59}$ NEVES, Guilherme Pereira das; NEVES, Lúcia Bastos Pereira das. Revolução. In: FERES JÚNIOR, João. Léxico da história dos conceitos políticos do Brasil. Belo Horizonte: Editora UFMG, p.387.
} 
Revolução Francesa vos mostrarão que as discussões públicas têm produzido mais resultados funestos, do que úteis" ${ }^{\circ 0}$.

Alguns meses depois, em junho de 1828, o redator da Aurora Fluminense se viu na obrigação de esclarecer seus leitores em relação aos significados que o termo revolução e seus derivados vinham tomando. Isso denota a percepção da politização e disputa semântica em cima do conceito. Para o periódico:

As palavras Revolução, Revolucionário, são uma espécie de talismã mágico, com que os governantes sabem a propósito fazer calar a opinião pública, e incutir terrores nos homens pacíficos, e moderados, e contudo as Revoluções são sempre filhas dos erros dos Governos [...]. É depois de se haver por todos os meios atormentado a população, calcado o seu amor próprio, ultrajado os seu prejuízos mais nobres, os direitos mais respeitáveis, que a indignação rompe todas as barreiras, e aparecem esses vulcões e lavas que levam tudo diante de $\mathrm{si}^{61}$.

Evaristo da Veiga parece identificar uma hipérbole ou um exagero acompanhando o conceito, e utilizada pela base de apoio do governo para desqualificar como revolucionários até mesmo o grupo moderado da oposição no qual se reconhecia. E ao criticar essa utilização do conceito e propor sua matização, acaba se lançando contra a concepção que considerava revolução como algo totalmente negativo.

Diferente de Silva Lisboa, Evaristo não vivenciou a Revolução Francesa, tendo recebido a elaboração dessa experiência como um traço cultural herdado. É possível, portanto, que esse referencial estivesse para ele muito mais aberto a reelaborações através de novas experiências ou de experiências mais recentes do que estava para o velho conservador. Em outubro de 1830, a Aurora Fluminense classificou a queda de Carlos X, na França, como "o mais belo elogio da última Revolução Francesa":

A revolução atual tem um caráter inteiramente novo: ela não terá o seu terror. Os Realistas [...] podem mostrar-se nos passeios públicos as suas pessoas serão respeitadas bem como suas propriedades[...]. Nada foi pilhado dos monumentos públicos, nada das casas particulares, nenhuma

\footnotetext{
${ }^{60}$ A Aurora Fluminense ${ }^{\circ} 32,9$ de abril de 1828.

${ }^{61}$ A Aurora Fluminense ${ }^{\circ} 59,25$ de junho de 1828
} 
violência se fez [...] Proteção das pessoas, respeito às propriedades: tal foi a palavra de ordem, e de reunião.

Um pouco mais a frente:

Estes e muito outros fatos de que estão cheios os jornais e os panfletos Franceses, fazem honra àquele povo, ou antes, mostram que o triunfo da civilização tem sido completo em Paris. Compare-se o povo de 27, 28 e 29 de Julho de 1830 com o de 20 de Junho e 10 de Agosto de 1792, a generosidade de homens que souberam não abusar de uma justa vitória, com os assassínios de Setembro ${ }^{62}$.

Desse modo, a Revolução de 1830 se coloca de maneira mais importante na ordem do dia na Aurora Fluminense, levando o redator inclusive a matizar a condenação da outra revolução, a de 1789, dividindo-a em duas fases: uma civilizada e a outra não. Denota-se dessa narrativa a possibilidade de revoluções benéficas, caso bem guiadas. A elaboração da experiência da Revolução de 1830 foi de suma importância para a ação política dos moderados na conjuntura do fim do primeiro reinado. Conforme Marcello Basile, esse evento "encontrou ampla receptividade na voz dos liberais brasileiros, que insinuavam haver uma associação, ditada pelo imputado caráter absolutista do governo, entre o monarca deposto da França e o imperador do Brasil" ${ }^{\prime 63}$.

A reelaboração do conceito de revolução encontra terreno mais fértil no jovem Evaristo da Veiga do que no velho Silva Lisboa. O primeiro, outrora categoricamente antirrevolucionário, em abril de 1831 terminou por apoiar o movimento que culminou na abdicação de D. Pedro I. Em 8 de abril de 1831, dia seguinte à queda do imperador, a Aurora Fluminense relatou: "uma revolução, a mais assombrosa por seus amplos efeitos e pela marcha que tem seguido, ocorreu no Brasil". No entanto, de forma diversa às experiências jacobina ou hispano americana, e por mais que o jornal colocasse ênfase na tensão e na possibilidade de ter havido caos, concluiu que "a ordem pública não foi perturbada um instante. Ninguém tem sido insultado por suas opiniões [...] Viva a Nação Brasileira, Viva a Constituição! Viva D. Pedro II, Imperador Constitucional!" ${ }^{4}$. A mesma narrativa foi reafirmada em abril de 1833, conformando a queda de D. Pedro I como "uma

\footnotetext{
${ }^{62}$ A Aurora Fluminense ${ }^{\circ}$ 406, 29 de outubro de 1830.

${ }^{63}$ BASILE, Marcello. A Revolução do 7 de Abril de 1831: disputas políticas e lutas de representações. XXVII Simpósio Nacional de História, 2013, Natal. Anais do XXVII Simpósio Nacional de História, 2013, p.1.

${ }^{64}$ A Aurora Fluminense ${ }^{\circ} 469,8$ de abril de 1831.
} 
revolução gloriosa [...] uma revolução necessária executada sem sangue e sem horrores"65.

\section{CONSIDERACÕES FINAIS}

Para além das datas de nascimento em si (posições geracionais), acreditamos que a investigação baseada na experiência e no desenvolvimento conceitual incidindo nas trajetórias e discursos políticos dos produtores de periódicos permite a apreciação da Independência também como um campo de ação multigeracional. Diferentes grupos, com acumulação de experiências diversas, tiveram importante participação nas variadas conjunturas políticas observáveis entre 1808 e 1831. E através dessa sucessão geracional, sob a força de diferentes conjunturas, conceitos como o de revolução foram sendo reelaborados e modificados, indicando novas experiências e novas expectativas de futuro, guiando, portanto, o processo de Independência por rotas, perspectivas e projetos diversos encontrados nas gerações mais primevas.

Todavia, cada conjuntura não significou espaço de atuação de apenas uma determinada e correspondente geração. Como vimos, nos anos finais do Primeiro Reinado, principalmente a partir de 1826, o encontro geracional - por vezes um choque - é mais evidente. Conceitualmente, revolução encontra variações e reelaborações conforme indivíduos mais novos passam a priorizar experiências mais recentes em detrimento das mais antigas. A própria ruptura entre Brasil e Portugal torna-se um referencial para revolução escamoteando outros eventos como a Revolução Francesa e as Independências Hispano-americanas.

Em termos mais empíricos, Silva Lisboa e Barata por partilharem vivências e experiências comuns, notadas pela semelhança no manuseio do termo revolução, possuem além da posição geracional, uma conexão geracional. São representantes, portanto, de uma geração mais antiga dentro do conjunto de nossos personagens. Uma geração, da qual uma das unidades geracionais pode ser considerada como a denominada “geração de 1790”, grupo do qual Silva Lisboa é representante, mas não Barata.

Entre esses dois produtores de periódicos, por um lado, e nomes como o de Ottoni, de outro, verificamos uma quebra geracional, conforme o conceito de revolução, nos

\footnotetext{
${ }^{65}$ A Aurora Fluminense ${ }^{\circ} 755,10$ de abril de 1833.
} 
discursos do redator do Sentinela do Serro, articula de maneira diferente antigas experiências, como a Revolução Francesa, além da incorporação de novas, como a própria ruptura entre Brasil e Portugal e a abdicação de D. Pedro I. Esse desenvolvimento semântico é percebido em discursos de indivíduos de posição geracional entre um extremo e outro, como em Evaristo da Veiga e sua Aurora Fluminense

No entanto, o conceito de revolução é apenas um exemplo de como novas gerações reelaboram experiências anteriores e as modificam em contato com novas. Entender o desenvolvimento mais amplo de processos e fenômenos históricos como a Independência em função da sucessão geracional é o tipo de investigação que se pode conceber a partir dessa abordagem.

\section{REFERÊNCIAS}

Fontes

Anais do Senado Federal, v.1, 1832.

Astro de Minas $\mathrm{n}^{\circ}$ 451, 9 de outubro de 1830.

A Aurora Fluminense, anos indicados.

O Conciliador do Reino Unido, anos indicados.

Honra do Brasil desafrontada de insultos da Astréa espadaxina, anos indicados.

Rebate brasileiro contra o Thyfis Pernambucano. Rio de Janeiro: Typographia Nacional, 1824.

LISBOA, José da Silva. Historia dos principais successos politicos do Imperio do Brasil dedicada ao senhor D. Pedro I. Rio de Janeiro: Typ. Imperial e Nacional, 1827-1830.

MARQUES, Cesar Augusto. Diccionario historico-geographico da província do Maranhão. Maranhão: Typ. do Frias, 1870, vol 2.

OTTONI, Teófilo. Circular dedicada aos srs. eleitores de senadores pela província de Minas Gerais. Rio de Janeiro: Typhografia do Correio Mercantil, 1860.

\section{Obras Gerais}

ARAUJO, Valdei Lopes. A experiência do tempo: conceitos e narrativas na formação 
nacional brasileira (1813-1845). São Paulo: Hucitec, 2008.

BANDECCHI, Brasil. Ledo: pensamento e ação nas lutas da Independência. São Paulo: Parma, 1983.

BASILE, Marcello. A Revolução do 7 de Abril de 1831: disputas políticas e lutas de representações. In: XXVII Simpósio Nacional de História, 2013, Natal. Anais do XXVII Simpósio Nacional de História, 2013.

BORGES, Luiz Adriano Gonçalves. Aspectos econômicos da participação paulista no processo de independência. Almanack, v. 6, 2013.

CASTRO JUNIOR, Sebastião Eugênio Ribeiro. Francisco Montezuma e os dilemas da mestiçagem e da cidadania no Império do Brasil (1820 - 1834). (Dissertação) Mestrado em História, Universidade Federal Fluminense, Niterói, 2014.

COELHO, Geraldo Mártires. Anarquistas, demagogos e dissidentes: a imprensa liberal do Pará de 1822. Bélem: Cejup, 1993.

DARNTON, Robert. A questão dos livros: presente, passado e futuro. São Paulo: Companhia das Letras, 2010.

DIAS, Maria Odila da Silva. Aspectos da Ilustração no Brasil. RIHGB, Rio de Janeiro, v.278, 1968.

ELIAS, Norbert. A sociedade dos indivíduos. Rio de Janeiro Jorge Zahar Editor, 1994.

FALCON, Francisco Calazans. KANTOR, Irís. Geração de 1790. In: VAINFAS, Ronaldo; NEVES, Lúcia Maria Bastos Pereira das. (Org.). Dicionário do Brasil Joanino (1808-1821). Rio de Janeiro: Objetiva, 2008.

FARIA JÚNIOR, Carlos de. O pensamento econômico de José da Silva Lisboa, Visconde de Cairu. (Tese) Doutorado em História, Universidade de São Paulo, São Paulo, 2008.

FERNÁNDEZ SEBASTIÁN, Javier (dir.), Diccionario político y social del mundo iberoamericano: La era de las revoluciones, 1750-1850. [Iberconceptos I], Madrid, Fundación Carolina / CEPC, 2009.

GONZÁLEZ DEMURO, Wilson. Prensa periódica y circulación de ideas en la Provincia Oriental, entre el final de la dominación española y la independencia (18141825). Uruguay: Universidad de la Republica, 2013.

HOBSBAWM, Eric J. A Era das Revoluções, Europa 1789-1848. Rio de Janeiro: Paz e Terra, 1977.

JANCSÓ, István. A Construção dos Estados Nacionais Na América Latina Apontamentos Para O Estudo do Império Como Projeto. In: LAPA, José Roberto do Amaral; SZMRECSÁNYI, Tamás. (Org.). História econômica da Independência e do Império. São paulo: Hucitec, 1996.

; PIMENTA, João Paulo Garrido. Peças de um mosaico (apontamentos para o estudo 
da emergência da identidade nacional brasileira. In: MOTA, Carlos Guilherme (Org.). Viagem Incompleta 1500-2000 - A experiências Brasileira. São Paulo: SENAC São Paulo Editora, 2000.

; SLEMIAN, Andrea. Um caso de patriotismo imperial. In: DINES, Alberto. (Org.). Hipólito José da Costa e o Correio Braziliense. Estudos. São Paulo; Brasília: Imprensa Oficial do Estado; Correio Braziliense, 2002.

KIRSCHNER, Tereza Cristina José da Silva Lisboa. Visconde de Cairu. Itinerários de um ilustrado luso-brasileiro. São Paulo: Alameda, 2009.

KOSELLECK, Reinhardt. Estratos do tempo: estudos sobre história. Rio de Janeiro: Contraponto: Editora PUC-Rio, 2014.

Futuro passado. Rio de Janeiro, Contraponto/PUC-Rio, 1999.

MACHADO, André Roberto de A. A quebra da mola real das sociedades: a crise política do antigo regime português na província do Grão-Pará (1821-1825). São Paulo: Hucitec / FAPESP, 2010.

MANNHEIM, Karl. El problema de las geraciones. REIS, nº 62, 1993.

MATTOSO, Katia Queiroz. Presença francesa no Movimento Democrático Baiano de 1798. Salvador: Itapuã, 1969.

MAXWELL, Kenneth. A geração de 1790 e a idéia do império luso-brasileiro. In: Chocolate, piratas e outros malandros: ensaios tropicais. São Paulo, Paz \& Terra, 1999.

MIRANDA, Leonardo Souza de Araújo. A Democracia da Gravata Lavada: Teófilo Ottoni, vida, identidade política, espaço público e republicanismo entre (1826-1842). (Dissertação) Mestrado em História, Universidade Federal de Minas Gerais, Belo Horizonte, 2008.

MOREL, Marco. As transformações dos espaços públicos: imprensa, atores políticos e sociabilidades na cidade imperial (1820 - 1840). São Paulo: Hucitec, 2005.

Cipriano Barata na Sentinela da Liberdade. Salvador: Academia de Letras da Bahia; Assembléia Legislativa do Estado da Bahia, 2001.

La génesis de la opinión pública moderna y el proceso de independencia (Río de Janeiro, 1820-1840). In: GUERRA, François-Xavier; LEMPÉRIÈRE, Annick.: Los espacios públicos en Iberoamérica. Ambigüedades y problemas. Siglos XVIII y XIX. México, Centro Francés de Estudios Mexicanos y Centroamericanos - FCE, 1998.

Sentinela da Liberdade e outros escritos (1811-1835). São Paulo: Edusp, 2009.

; BARROS, Mariana Gonçalves Monteiro de. Palavra, imagem e poder: o surgimento da imprensa no Brasil do século XIX. Rio de Janeiro: DP\&A, 2003

NEVES, Guilherme Pereira das. Pálidas e oblíquas luzes: José Joaquim da Cunha de Azeredo Coutinho e a Análise sobre a justiça do comércio do resgate dos escravos. In: 
SILVA, Maria Beatriz Nizza da (Org.). Brasil: colonização e escravidão. Rio de Janeiro: Nova Fronteira, 2000.

; NEVES, Lúcia Bastos Pereira das. Revolução. In: FERES JÚNIOR, João. Léxico da história dos conceitos políticos do Brasil. Belo Horizonte: Editora UFMG, 2014.

NOVAIS, Fernando Antonio. Portugal e Brasil na crise do antigo sistema colonial. São Paulo: Hucitec, 2005.

OLIVEIRA, Carlos Eduardo França. Poder local e palavra impressa: a dinâmica política em torno dos Conselhos Provinciais e da imprensa periódica em São Paulo, 1824- 1834. Dissertação (Mestrado em História), Universidade de São Paulo, São Paulo, 2009.

PIMENTA, João Paulo. A Independência do Brasil e a experiência hispano-americana (1808-1822). São Paulo: Hucitec, 2015.

A independência do Brasil como uma revolução: história e atualidade de um tema clássico. História da Historiografia: International Journal of Theory and History of Historiography, v. 2, n. 3, p. 53-82, 2009.

. Tempos e espaços das independências: a inserção do Brasil no mundo ocidental (c.1780-c.1830). Tese de Livre Docência, Universidade de São Paulo, São Paulo, 2012.

; FANNI, Rafael. Revolución en Brasil: la historia de un concepto, un concepto en la historia (siglos XVIII-XXI). In: WASSERMAN, Fabio (Org.). El mundo en movimiento: el concepto de revolución en Iberoamérica y el Atlántico norte (siglos XVIIXX). Buenos Aires: Miño y Dávila, 2019.

PRADO JUNIOR, Caio. Evolução Política do Brasil. São Paulo: Brasiliense, 1971.

RICCI, Maria Lúcia de Souza Rangel. A atuação política de um publicista: Antônio Borges da Fonseca. PUC: Campinas, 1995.

RIZZINI, Carlos. Hipólito da Costa e o Correio Braziliense. Cia Editora Nacional: São Paulo; 1957.

ROCHA, Antonio Penalves. José da Silva Lisboa, visconde de Cairu. São Paulo: Ed. 34, 2001.

SARAIVA, Luis Manuel Ribeiro. Manoel Ferreira de Araújo Guimarães (1777-1838): From the Navy Royal Academy to the Royal Military Academy of Rio de Janeiro. Rev. Bras. de História da Matemática, v. 11, n. 21, São Paulo, 2011.

SILVA, Ana Rosa Cloclet da. Inventando a nação. São Paulo: Hucitec, 2006.

VIANNA, Helio. Contribuição à história da imprensa brasileira (1812-1869). Rio de Janeiro: Instituto Nacional do Livra, 1945.

VIDIGAL, Geraldo. O Marquês de Monte Alegre: alvorecer de um estadista. São Paulo: Ibrasa, 1998. 
REVISTA ÁGOQRA, v. 31, n. 3, e-2020310301, 2020, ISSN: 1980-0096

VIEIRA, Luis Otávio. Origens da imprensa no Brasil: estudo prosopográfico dos redatores e editores de periódicos publicados entre 1808 e 1831. Dissertação (Mestrado em História), Universidade de São Paulo, São Paulo, 2019.

WELLER, Wivian. A atualidade do conceito de gerações de Karl Mannheim. Sociedade e Estado, v. 25, 2010.

Recebido em: 17/09/2020 - Aprovado em: 18/11/2020 